2001 97: 557-564

doi:10.1182/blood.V97.2.557

\title{
Allogeneic chimerism with low-dose irradiation, antigen presensitization, and costimulator blockade in $\mathrm{H}-2$ mismatched mice
}

Peter J. Quesenberry, Suju Zhong, Han Wang and Marc Stewart

Updated information and services can be found at:

http://bloodjournal.hematologylibrary.org/cgi/content/full/97/2/557

Articles on similar topics may be found in the following Blood collections:

Transplantation (1259 articles)

Immunobiology (3426 articles)

Information about reproducing this article in parts or in its entirety may be found online at:

http://bloodjournal.hematologylibrary.org/misc/rights.dtl\#repub_requests

Information about ordering reprints may be found online at:

http://bloodjournal.hematologylibrary.org/misc/rights.dtl\#reprints

Information about subscriptions and ASH membership may be found online at:

http://bloodjournal.hematologylibrary.org/subscriptions/index.dtl

Blood (print ISSN 0006-4971, online ISSN 1528-0020), is published

semimonthly by the American Society of Hematology, 1900 M St, NW, Suite 200, Washington DC 20036.

Copyright 2007 by The American Society of Hematology; all rights reserved.

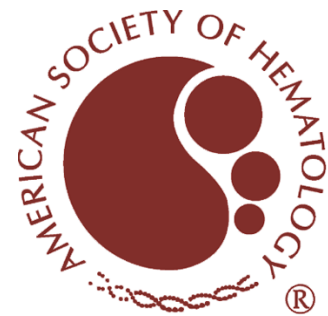




\title{
Allogeneic chimerism with low-dose irradiation, antigen presensitization, and costimulator blockade in $\mathrm{H}-2$ mismatched mice
}

\author{
Peter J. Quesenberry, Suju Zhong, Han Wang, and Marc Stewart
}

\begin{abstract}
We have previously shown that the keys to high-level nontoxic chimerism in syngeneic models are stem cell toxic, nonmyelotoxic host treatment as provided by 100 cGy whole-body irradiation and relatively high levels of marrow stem cells. This approach was unsuccessful in $\mathrm{H}-2$ mismatched B6.SJL to BALB/c marrow transplants, but with tolerization, stable multilineage chimerism was obtained. Ten million B6.SJL spleen cells were infused intravenously into BALB/c hosts on day
\end{abstract}

-10 and (MR-1) anti-CD40 ligand monoclonal antibody (mAb) injected intraperitoneally at varying levels on days $-10,-7$, $-3,0$, and +3 and the BALB/c mice irradiated (100 cGy) and infused with 40 million B6.SJL/H-2 mismatched marrow cells on day 0 . Stable multilineage chimerism at levels between $30 \%$ to $40 \%$ was achieved in the great majority of mice at $1.6 \mathrm{mg}$ anti-CD40 ligand $m A b$ per injection out to 64 weeks after transplantation, without graft-versus-host disease. The transplanted mice were also tolerant of donor B6.SJL, but not third-party CBA/J skin grafts at 8 to 9 and 39 to 43 weeks after marrow transplantation. These data provide a unique model for obtaining stable partial chimerism in $\mathrm{H}-2$ mismatched mice, which can be applied to various clinical diseases of man such as sickle cell anemia, thalassemia, and autoimmune disorders. (Blood. 2001;97:557-564)

๑) 2001 by The American Society of Hematology

\section{Introduction}

Dogma has held that cytotoxic ablative therapy was needed to open space and allow for marrow stem cell engraftment. ${ }^{1}$ Reports by a number of investigators established that engraftment could be obtained in nonmyeloablated mice, but some dismissed this as not significant. $^{2-6}$ We have modeled our initial studies on those of Brecher and coworkers ${ }^{5}$ and established that at the stem cell level, engraftment is quantitatively complete in the absence of any cytoablative treatment; the final differentiated phenotype of engraftment is determined by the ratio of host/donor stem cells. ${ }^{7-10}$ Mathematical modeling indicated that the final level of differentiated donor hematopoietic cells in transplanted mice related directly to the ratio of infused donor marrow cells to total host marrow cells. ${ }^{11}$ This relationship holds because the relative numbers of differentiated donor and host cells in transplanted mice presumably reflects the relative number of donor and host lymphohematopoietic stem cells.

These data, indicating that engraftment in a syngeneic setting was determined solely by stem cell competition, were confirmed by studies in mice subjected to $100-c G y$ whole-body irradiation (WBI) and transplanted with varying levels of marrow cells. ${ }^{12}$ Here with a male $\mathrm{BALB} / \mathrm{c}$ to female $\mathrm{BALB} / \mathrm{c}$ transplant model, engraftment generally correlated inversely with numbers of host engraftable stem cells. This level of irradiation proved to be relatively nonmyelotoxic, but quite stem cell toxic, and high levels of stable long-term multilineage chimerism could be obtained with lower, but still relatively high, levels of infused marrow cells.

These studies suggested strategies for creating nontoxic chimerism in allogeneic stem cell transplantation using (1) nonmyelotoxic, but stem cell toxic, host treatment (100 cGy) and (2) relatively high levels of donor stem cells. Initial studies with B6.SJL to BALB/c H-2 incompatible murine marrow transplants, using 100-cGy host treatment and 40 million infused marrow cells, failed to show engraftment and indicated that tolerizing approaches were probably needed.

To initiate an effective T-cell response to antigen, 2 activation signals are needed. The primary interaction is between the antigenmajor histocompatibility complex (MHC) and the T-cell receptor, but an interaction between a costimulatory molecule and its receptor is also necessary. Two major costimulatory pathways continue to be defined. The B7 (CD80 and CD86) family of molecules on antigen-presenting cells (APC) binds to T-cell antigens CD28 and CTLA4, ${ }^{13-16}$ whereas CD40 molecules on APC bind to CD40 ligand on T cells. ${ }^{17-21} \mathrm{~T}$ cells receiving the MHCantigen-T-cell receptor signal in the absence of a costimulatory signal become anergic or are depleted..$^{22-28}$ However, cytotoxic T lymphocytes receiving both activation signals can then expand clonally and respond to target cells expressing the MHC-antigen complex. Blocking these costimulator pathways presented attractive approaches to establishing antigen-specific tolerance. Early studies showed survival of cardiac allografts ${ }^{29}$ and xenogeneic islet grafts in mice ${ }^{30}$ using CTLA4 Ig inhibition of the B7-CD28 pathway, although other studies indicated that blockade of either the B7-CD28 or CD40-CD40 ligand pathways alone was insufficient to permit engraftment of highly immunogenic allografts. ${ }^{31-33}$ Use of a double blockade of CD40 and CD28 pathways allowed engraftment of alloantigen MHC-mismatched cardiac and skin grafts $^{34}$ and xenogeneic rat to mouse cardiac and skin grafts and pig skin to mouse grafts. ${ }^{35}$ Anti-CD40 ligand monoclonal antibody
From the Cancer Center, University of Massachusetts Medical Center, Worcester, MA

Submitted January 13, 2000; accepted September 19, 2000.

Supported by National Heart, Lung, and Blood Institute, National Institutes of Health (NIH), grant PO1-HL56920 and National Institute of Diabetes and Digestive and Kidney Diseases, NIH, grants P01-DK50222, RO1-DK49650, and RO1-DK27424.
Reprints: Peter J. Quesenberry, Professor of Medicine, Cancer Center, University of Massachusetts Medical Center, NRI Building, Room 211, 55 Lake Avenue North, Worcester, MA 01655; e-mail: peter.quesenberry@umassmed.edu.

The publication costs of this article were defrayed in part by page charge payment. Therefore, and solely to indicate this fact, this article is hereby marked "advertisement" in accordance with 18 U.S.C. section 1734.

(c) 2001 by The American Society of Hematology 
(mAb) was found to block acute and chronic graft-versus-host disease (GVHD) and to decrease alloreactive $\mathrm{CD}^{+}{ }^{+}$thoracic duct lymphocytes. ${ }^{36,37}$ Wekerle and colleagues ${ }^{38}$ reported on costimulator blockade in mice conditioned with 300 cGy total body irradiation (TBI) and infused with hematopoietic marrow cells. They found use of CTLA4 Ig or anti-CD40 ligand mAb alone resulted in transient chimerism, but the use of both agents resulted in stable long-term hematopoietic chimerism $(>40 \%$ and $>8$ months). The use of both agents was also effective in prolonging primate kidney grafts. ${ }^{39}$

Some investigators had shown that pretreatment with allogeneic $\mathrm{T}$ cells may tolerize and antigen presentation without costimulation leads to T-cell nonresponsiveness. ${ }^{22-28}$ These studies focused on CD28/B7 blockade with CTLA4 Ig. CTLA4 Ig was used in combination with donor antigen, 100-cGy total-body irradiation, and immunosuppression with mycophenolate mofetil and cyclosporine to obtain hematopoietic chimerism in dogs. ${ }^{40}$ Costimulation can also be prevented by blocking anti-CD40/CD154 interaction and subsequent up-regulation of B $7^{41-43}$ and anti-CD40 ligand/CD40 blockade with anti-CD40 ligand mAb combined with donor cell pre-exposure was used to obtain allogeneic murine pancreatic islet grafts ${ }^{44-46}$ and xenogeneic rat islet and skin grafts in mice. ${ }^{47,48}$

We have used spleen cell antigen pre-exposure and concomitant blockade of the CD40/CD40 ligand pathway combined with nonmyelotoxic/stem cell toxic host treatment (100 cGy) and high levels of marrow cells (40 million) in an H-2 mismatched B6.SJL to $\mathrm{BALB} / \mathrm{c}$ marrow transplant model to obtain stable long-term allochimerism.

\section{Materials and methods}

\section{Animals}

The B6.SJL $\left(\mathrm{H}-2^{\mathrm{b}}\right)$ and $\mathrm{CBA} / \mathrm{J}\left(\mathrm{H}-2^{\mathrm{k}}\right)$ mice were obtained from the Jackson Laboratory (Bar Harbor, ME). BALB/c(H-2d) mice were obtained from Taconic Farm (Taconic, NY). Mice were certified to be specific pathogen free, housed in our animal facility, and given ad libitum access to autoclaved food and acid water. They were maintained in accordance with local and federal guidelines (Department of Health, Education and Welfare Publication, National Institutes of Health [NIH] 78-23, 1985). These studies were approved by the University of Massachusetts Institutional Animal Care and Use Committee (IACUC) Docket: IACUC approval date 3/22/99. Animal Welfare assurance number A3306-01. The mice in our facility have been tested for Sendai virus (SEN), pneumonia virus of mice (PVM), mouse hepatitis virus (MHV), minute virus of mice (MVM), mouse polio virus (GD-7), reovirus type 3 (REO-3), Mycoplasma pulmonis (MPUL), mouse parvovirus (MPV), epizootic diarrhea of infant mice virus (EDIM), lymphocytic choriomeningitis virus (LCMV), mouse adenovirus FL/K87 (MAD), ectromelia virus (ECTRO), mouse pneumonitis virus (K), and polyoma virus (POLY). They were all negative for those tests.

\section{Bone marrow transplantation}

Normal male B6.SJL mice (age 6-8 weeks, weight 16-18 g) were used as donors and male BALB/c mice (age 6-8 weeks, weight 16-18 g) as recipients. B6.SJL marrow cells were flushed from tibia and femurs into sterile phosphate-buffered saline (PBS) with a syringe and 25-gauge needle. Sterile cells were resuspended with $5-\mathrm{mL}$ pipettes into a single cell suspension and passed through a $40 \mu \mathrm{m}$ cell strainer. Cell number was counted in crystal violet and $40 \times 10^{6}$ bone marrow cells were injected intravenously into each recipient (day 0 ).

\section{Donor cell phenotype analysis after transplantation (FACS analysis)}

Peripheral blood was collected from each transplant mouse by eye bleeding starting 3 weeks after transplantation. Fifty microliters was used to do labeling with fluorescein isothiocyanate (FITC)-conjugated CD45.1 (A-20 line, PharMingen, San Diego, CA). Donor cell percentage in recipient was determined as FITC-positive cells divided by total cell number. B6.SJL blood was used as positive control, with labeling in the range of $95 \%$ to $98 \%$, and BALB/c blood was used as negative control with the range of $1 \%$ to $2 \%$. FITC-conjugated CD3 (clone 17A2), biotin-conjugated CD19 (clone 1D3), and biotin-conjugated Gr-1 (clone RB6-8C5) were used to label the T cells, B cells, and granulocytes, respectively, when doing the sublineage analysis of engrafted cell phenotype. Donor cells were labeled with CD45.1 antibody. All antibodies are from PharMingen.

\section{Donor-specific tolerance}

Normal male B6.SJL (age 6-8 weeks, weight 16-18 g) spleen cells $\left(10 \times 10^{6}\right)$ were injected by tail vein 10 days before bone marrow transplant and anti-CD40 ligand antibody injected intraperitoneally immediately before the injection of B6.SJL spleen cells (day -10$)$ and then on days $-7,-3,0$, and +3 ("standard protocol").

\section{Murine anti-CD40 ligand mAb production and quantification}

The MR-1 hybridoma cell line (gift from Dr Randolph Noelle, Dartmouth Medical School, Dartmouth, $\mathrm{NH}$ ) produces murine anti-CD40 ligand mAb. The isotype of this antibody is Armenian hamster IgG, group 3, к. Briefly, BALB/c SCID mice (Jackson Laboratory) were primed with $0.5 \mathrm{~mL}$ Pristane (2,6,10.14-tetramethylpentadecane; Sigma Chemical, St Louis, MO) intraperitoneally. Seven to 10 days after the Pristane priming, $2 \times 10^{6}$ MR-1 cells (viability $>75 \%$ ) were injected intraperitoneally into each of the BALB/c SCID mice. Ascites was apparent by 7 to 10 days after cell injection and was then drained with sterile needles every other day. Freshly collected ascites was incubated at $37^{\circ} \mathrm{C}$ for 1 hour, then $4^{\circ} \mathrm{C}$ overnight. After centrifugation at $3000 \mathrm{rpm}$ for 30 minutes, supernatant was filtered through a $0.2-\mu \mathrm{m}$ filter. Samples were aliquoted and stored at $-80^{\circ} \mathrm{C}$. These were thawed immediately before injection into mice.

Enzyme-linked immunosorbent assay (ELISA) was used to quantitate the amount of Armenian hamster IgG in the ascites. The ELISA plates (Becton Dickinson, CA) were coated with $100 \mu \mathrm{L}$ capture antibody (affinity purified goat anti-Armenian hamster $\operatorname{IgG}$ ) and incubated at $4{ }^{\circ} \mathrm{C}$ overnight. Unknown concentration ascites and commercial anti-CD40 ligand antibody (PharMingen) were added to appropriate wells after serial dilution for $4^{\circ} \mathrm{C}$ overnight. Biotinylated goat antihamster IgG was added to the wells followed by avidin-horseradish peroxidase at appropriate dilutions. TMB Peroxidase EIA Substrate Kit (Bio-Rad, Hercules, CA) was used for detection and plates read at $650 \mathrm{~nm}$. Standard curves were made from the commercial anti-CD40 ligand antibody preparation and unknown ascites concentrations calculated based on the standard curves.

\section{Skin graft transplantation}

Skin was removed from the abdomen of euthanized murine B6.SJL $\left(\mathrm{H}-2^{\mathrm{b}}\right)$ or $\mathrm{CBA} / \mathrm{J}\left(\mathrm{H}-2^{\mathrm{k}}\right)$ donors with chloride hydrate anesthesia, and the underside was gently scraped with a scalpel to remove fat and muscle. Prepared skin was placed on sterile filter paper moistened with Hanks balanced salt solution (HBSS) buffered with HEPES (pH 7.4; Sigma Chemical) and kept at room temperature until used within 2 hours. The dorsal thoracic surfaces of anesthetized recipient mice were shaved and washed with $70 \%$ ethanol. A graft bed was prepared with fine scissors by removing an area of epidermis and dermis down to the level of the intrinsic muscle. Grafts 1.0 to $1.5 \mathrm{~cm}^{2}$ in area were fitted to the prepared bed without suturing and then covered with Vaseline-impregnated gauze and an adhesive plastic bandage. After 6 days, the bandage was removed. Skin graft survival was assessed 3 times a week by visual and tactile examination. Rejection was defined as the first day on which the entire epidermal surface of the graft was necrotic. 
Figure 1. Effect of host irradiation on B6.SJL engraftment into BALB/c hosts. BALB/c recipient mice were either unirradiated or subjected to 100 to 600 cGy WBI and then infused with 40 million B6.SJL marrow cells. The percentage (\%) donor $\left(\mathrm{CD} 45.1^{+}\right)$ cells in peripheral blood \pm 1 SEM are presented out to 21 weeks after transplantation. There were 4 mice per group at $400 \mathrm{cGy}$ and $500 \mathrm{cGy}$ and 5 mice per group at all other levels. After 9 weeks the 100-cGy groups dropped to 4 mice. Values for the 600-cGy group were significantly different from the $0-, 200-$, and 300-cGy groups at all time points out to 21 weeks $(P<.05)$.

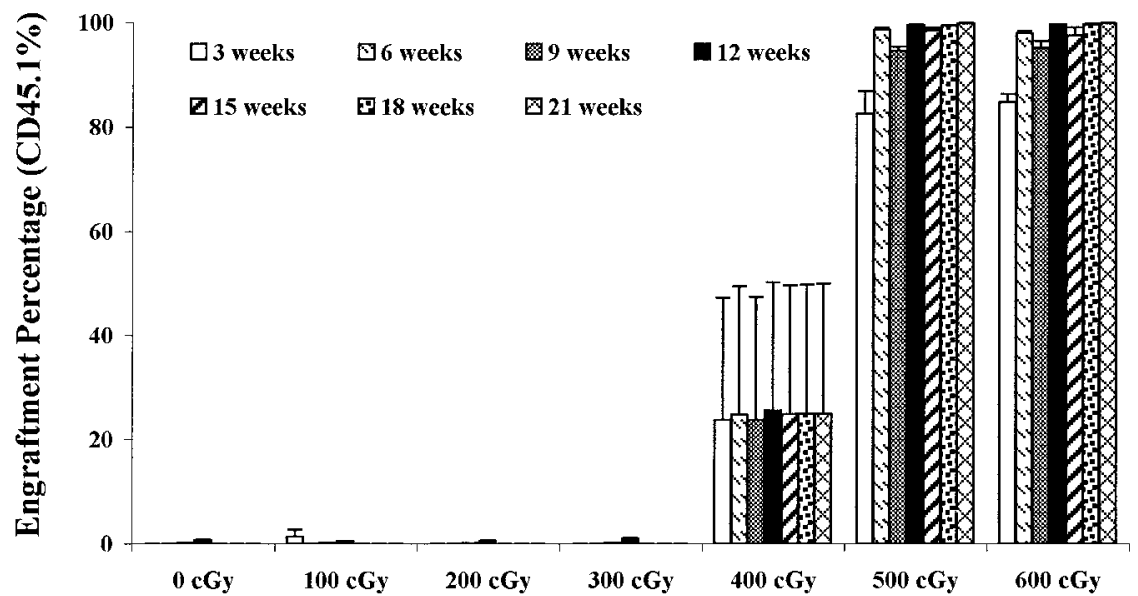

Radiation Dose

\section{Statistics}

The nonparametric Wilcoxon rank-sum test is used for comparison. The trend test developed by Cuzick was used for testing trend. ${ }^{49}$ The level of statistical significance is set at .05 (2-sided). Data are presented as mean \pm 1 SEM.

\section{Results}

\section{H-2 mismatched transplant without costimulator blockade}

In the initial studies we attempted to apply the strategy of 100-cGy BALB/c host irradiation with infusion of 40 million B6.SJL marrow cells. As shown in Figure 1, at $100 \mathrm{cGy}$, there was essentially no engraftment. In a few experiments relatively low levels of engraftment have occurred sporadically, but overall at this level of irradiation with this number of cells and 100-cGy host irradiation, marrow is rejected. As shown in Figure 1, stable long-term chimerism was not achieved until sublethal levels of single-dose irradiation (400-500 cGy) were delivered to the BALB/c hosts.

\section{B6.SJL engraftment in C57BL/6 mice}

In previous studies using 40 million $\mathrm{BALB} / \mathrm{c}$ cells into 100cGy-treated BALB/c hosts, we have obtained relatively high levels of chimerism, ordinarily above $60 \%$ out to 8 months after marrow infusion. ${ }^{12}$ We determined the levels of syngeneic chimerism when B6.SJL, H-2 compatible marrow cells were infused into C57BL/6 hosts. This combination should be histocompatible. As shown in Figure 2, levels between $20 \%$ and $30 \%$ chimerism were obtained. Twenty-one week engraftment was also determined in marrow, spleen, thymus, and peripheral blood. Engraftment levels of blood, spleen, thymus, and marrow were $23.2 \% \pm 9.3 \%, 25.3 \% \pm 8.2 \%$, $28.4 \% \pm 13.6 \%$, and $14.9 \% \pm 5.3 \%$, respectively. BALB/c and $\mathrm{C} 57 \mathrm{BL} / 6 \mathrm{~J}$ mice evidence different results when radiation sensitivity is assessed. ${ }^{50} \mathrm{LD}_{50 / 30}$ values for 4-month-old female BALB/cJ and C57BL/6J mice were $616 \pm 12.8 \mathrm{cGy}$ and $705 \pm 6.2 \mathrm{cGy}$, respectively, indicating that $\mathrm{BALB} / \mathrm{cJ}$ mice were $13 \%$ more sensitive to radiation when this parameter was measured. However, if endogenous spleen colony survival was assessed, C57BL/6J had $\mathrm{D}_{0}\left(\mathrm{D}_{0}\right.$ reduces survival by a factor of 0.37$)$ values of $65 \pm 4.4 \mathrm{cGy}$, whereas BALB/cJ mice gave values of $79.4 \pm 5.8 \mathrm{cGy}$, indicating that $\mathrm{C} 57 \mathrm{BL} / 6 \mathrm{~J}$ were $18 \%$ more sensitive to irradiation when this parameter was measured. At the most, $\mathrm{C} 57 \mathrm{BL} / 6 \mathrm{~J}$ are not more than $20 \%$ more sensitive to irradiation than BALB/c mice. Thus, the present results suggest a "BALB/c equivalent" maximum for C57BL/6J engraftment, under the conditions of these experiments, of approximately $40 \%$, significantly less than seen with a male $\mathrm{BALB} / \mathrm{c}$ to female $\mathrm{BALB} / \mathrm{c}$ transplantation.

\section{Antigen pre-exposure and costimulator blockade in $\mathrm{H}-2$ mismatched murine marrow transplantation}

We evaluated the addition of antigen pre-exposure and costimulator blockade to the model of infusing 40 million $\mathrm{H}-2$ mismatched B6.SJL cells into 100-cGy-treated BALB/c hosts. Here, as described in "Materials and methods," 10 million B6.SJL spleen cells were infused by tail vein 10 days prior to transplantation and varying dose levels of anti-CD40 ligand antibody were given immediately prior to the spleen cell infusion and thereafter on days $-7,-3,0$, and +3 . On day 0,40 million B6.SJL whole marrow cells were infused into BALB/c hosts, which had received $100 \mathrm{cGy}$ within 4 hours of marrow infusion. Figure 3 presents long-term results in experiments evaluating graded doses of antibody in this model. Here we see that long-term allochimerism at levels ranging
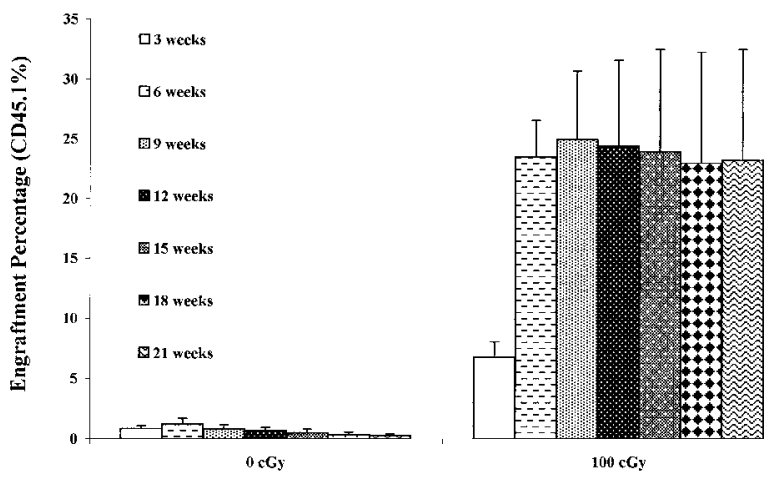

Figure 2. Engraftment of B6.SJL marrow in C57BL/6 hosts. Forty million male B6.SJL marrow cells were infused into nonirradiated (0 cGy) or irradiated (100 cGy) C57BL/6 male hosts and percent engraftment in peripheral blood determined out to 21 weeks after transplantation. Data are presented as percentage (\%) engraftment \pm 1 SEM. There were 5 mice per group and engraftment was evaluated by CD45.1 labeling FACS analysis on individual mice. Values in the 100-cGy group were significantly different from the 0 -cGy group at all time points $(P<.05)$. At 21 weeks, engraftment was also determined in marrow, spleen, and thymus, along with peripheral blood. Percent engraftment levels in blood, spleen, thymus, and marrow were $23.2 \pm 9.3,25.3 \pm 8.2,28.4 \pm 13.6$ and $14.9 \pm 5.3$, respectively. 


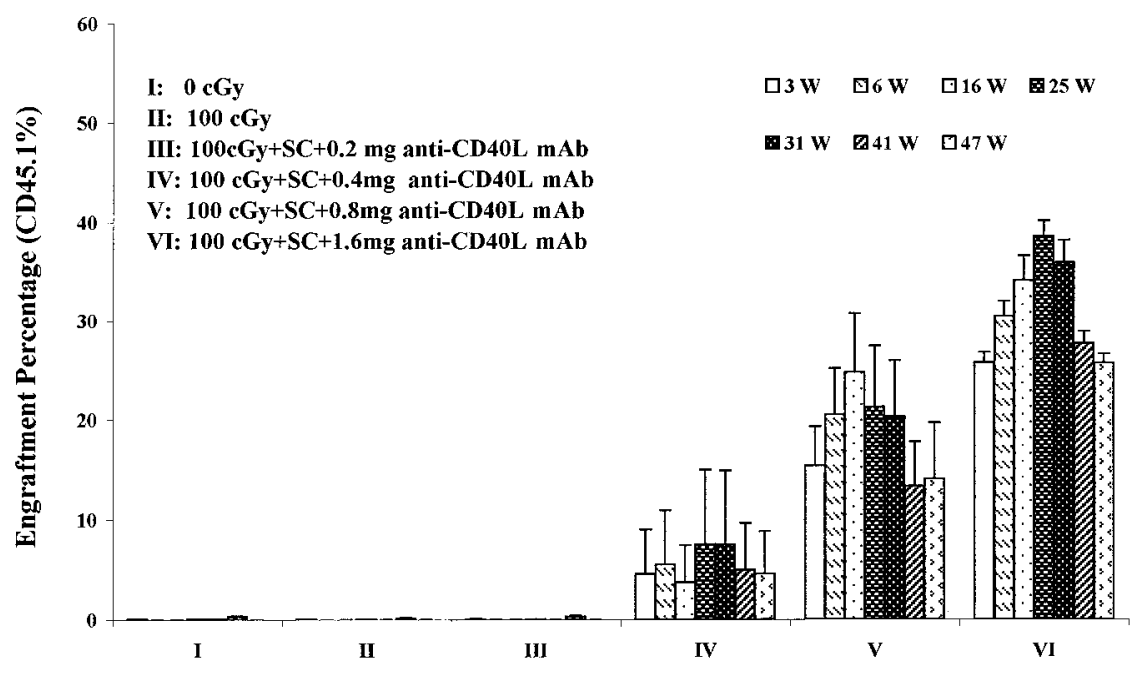

Figure 3. Engraftment of B6.SJL marrow into 100cGy irradiated BALB/c hosts pre-exposed to B6.SJL spleen cells and treated with anti-CD40 ligand (L) monoclonal antibody (mAb). BALB/c hosts were infused with 10 million B6.SJL spleen cells (SC) on day -10 . Immediately before spleen cell infusion and on days $-7,-3,0$, and +3 BALB/c hosts were injected with varying amounts of anti-CD40 ligand $(\mathrm{mAb})$ intraperitoneally. These mice were subjected to 100-cGy WBI and infused with 40 million B6.SJL marrow cells on day 0 . Donor chimerism was determined by staining peripheral blood cells with CD45.1 antibody and analyzing individual mice by FACS. Data are expressed as percent engraftment out to 47 weeks after transplantation. There were initially 5 mice per group. Group I had 4 mice per group after week 9 , and group VI had 4 mice per group after week 16. At 47 weeks, smaller numbers of mice were in each group due to the use of mice for other experimental points. Groups V and VI were statistically different from groups I, II, and III at all time points, $P<.02$ and $P<.01$, respectively. $W$ indicates weeks. from $30 \%$ to $40 \%$ were obtained out to 47 weeks after marrow infusion, at the 1.6-mg per injection antibody level. If spleen cells were given with this approach, but marrow was not infused, no engraftment was seen.

Multilineage engraftment was evaluated at 22 and 35 weeks after transplantation (Figure 4). In each instance engraftment was seen in the T-cell, B-cell, and granulocyte lineages. The distribution of each type was similar to that seen in normal B6.SJL mice, although donor CD19 percentages were relatively lower in the transplanted mice. We also evaluated engraftments in marrow, spleen, blood, and thymus at 50 weeks in selected mice from this experiment (Table 1). Multiorgan engraftment was seen, but with relatively lower levels of bone marrow engraftment due to a failure of the anti-CD45.1 mAb to react with erythroid precursors.

Stable chimerism has now been observed out to 64 weeks in 2 mice given this "standard protocol" (1.6 mg anti-CD40 ligand antibody) at $29.1 \%$ and $29.3 \%$. In a total of 30 mice, using the "standard protocol" with $1.6 \mathrm{mg}$ of anti-CD40 ligand monoclonal antibody and -day 10 spleen cell pre-exposure, evaluated at 9 weeks, the mean marrow engraftment $\pm 1 \mathrm{SE}$ was $28.9 \% \pm 3 \%$. Seven of the 30 mice showed no, or very low, levels of engraftment (up to $3.1 \%$ ). If the 23 mice showing higher levels of engraftment

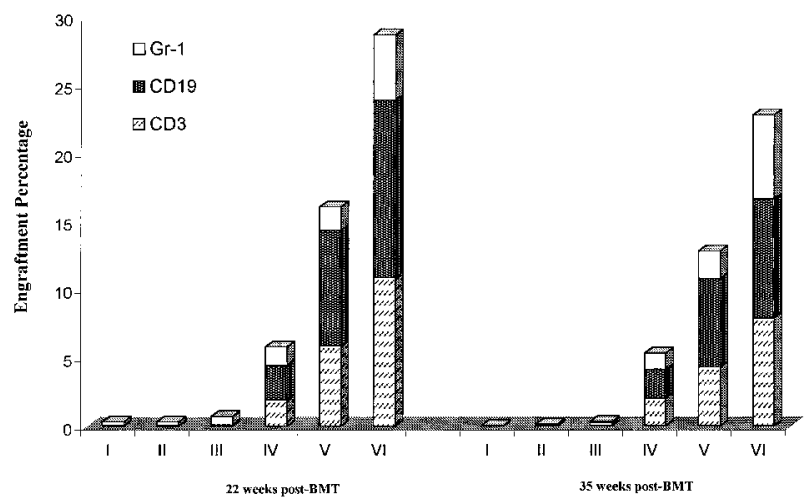

Figure 4. Multilineage engraftment of B6.SJL marrow into 100-cGy-irradiated BALB/c hosts preexposed to B6.SJL spleen cells and treated with anti-CD40 ligand $\mathbf{m A b}$. Engrafted mice described in Figure 3 were analyzed for multilineage engraftment by determining the percentage of cells in the host peripheral blood labeled with both CD45.1 and either CD3 (T cells), CD19 (B cells), or Gr-1 (granulocytes) and analyzed by FACS (see "Materials and methods") at 22 and 35 weeks after transplantation. Data are presented as mean percentage engraftment of donor CD3, CD19, or Gr-1 cells \pm SEM. There were 4 to 5 mice per group. were analyzed, the mean engraftment level was $37.4 \% \pm 1.6 \%$. These values suggest, when compared to engraftment seen with B6.SJL into C57BL/6 mice, that a relatively high level of engraftment was obtained at the cell level of 40 million donor marrow cells in these B6.SJL to BALB/c transplants, using the "standard protocol."

We further evaluated whether a spleen cell injection was required for induction of allochimerism. We also evaluated spleen cell administration at -7 or -10 days in the same experiments. Here, as shown in Figure 5, it was clear that omission of antigen preexposure with spleen cell injection resulted in no (or very low) chimerism. Alteration between day 7 and 10 had relatively little effect, but these results indicated that, in the context of this model, spleen cell infusion was needed to obtain full allochimerism. The impact of a secondary marrow transplant of 40 million B6.SJL cells between weeks 12 and 13 was assessed in mice in these experiments (asterisks in Figure 5). There was no augmentation of engraftment seen in groups I and V to VIII, but the 0 cGy groups treated with CD40 ligand antibody, and especially with spleen presensitization, showed an augmentation of engraftment, suggesting that secondary transplantation may be useful in these models.

We next investigated whether altering cell dose would affect allochimerism. In Figure 6 we show results when 40 million, 80 million, or 120 million marrow cells were infused in the "standard protocol." Increasing the number of cells to 80 million significantly increased allochimerism, whereas there was little further increase with an increase to 120 million cells. Evaluation of engraftment in the spleen, thymus, marrow, and blood of 2 mice in the 80 million and 2 mice in the 120 million cell groups showed multiorgan engraftment that was relatively similar for all groups except thymus, which showed higher levels (data not shown) of engraftment, as compared to the other tissues.

The previous data showing an antibody dose-response curve out to 41 weeks was followed by further escalations of antibody levels in the "standard protocol." In Figure 7 we show that increasing anti-CD40 ligand antibody to $3.2 \mathrm{mg} /$ injection further increased the level of allochimerism. In separate studies (data not shown) we have established that $1.6 \mathrm{mg}$ of control hamster IgG used, instead of anti-CD40 ligand antibody, in the full spleen pre-exposure costimulator blockade B6.SJL to BALB/c transplant model did not result in allochimerism. In further studies we have used ELISA to determine anti-CD40 ligand hamster mAb levels in murine blood. Levels of antibody remained detectable out to 15 weeks after the 
Table 1. Comparison of engraftment level in different organs at 50 weeks after transplantation

\begin{tabular}{|c|c|c|c|c|c|}
\hline$I D^{*}$ & Group & $\mathrm{BM} \dagger(\%)$ & PB (\%) & Spleen (\%) & Thymus (\%) \\
\hline $\mathrm{BALB} / \mathrm{c}$ & & 0 & 0 & 0 & 0 \\
\hline B6.SJL & & 82.68 & 93.79 & 98.44 & 95.24 \\
\hline 11 & $0 \mathrm{cGy} / 40 \times 10^{6}$ & 0.3 & 0 & 0.16 & 0.21 \\
\hline 12 & 0 cGy $/ 40 \times 10^{6}$ & 0.13 & 0 & 0 & 0 \\
\hline IV4 & $100 \mathrm{cGy} / 0.4 \mathrm{mg}$ anti-CD $40 \mathrm{~L} \mathrm{mAb} / 40 \times 10^{6}$ & 12.45 & 24.4 & 34.54 & 21.49 \\
\hline IV5 & $100 \mathrm{cGy} / 0.4 \mathrm{mg}$ anti-CD $40 \mathrm{~L} \mathrm{mAb} / 40 \times 10^{6}$ & 0 & 0 & 0 & 0 \\
\hline V1 & $100 \mathrm{cGy} / 0.8 \mathrm{mg}$ anti-CD $40 \mathrm{~L} \mathrm{mAb} / 40 \times 10^{6}$ & 4.22 & 11.26 & 24.21 & 10.58 \\
\hline V2 & $100 \mathrm{cGy} / 0.8 \mathrm{mg}$ anti-CD40L mAb/40 × $10^{6}$ & 18.34 & 30.05 & 58.64 & 24.79 \\
\hline
\end{tabular}

BM indicates bone marrow; PB, peripheral blood.

*Identification of individual mice in groups I, IV, and V from Figure 3.

†The lower numbers in the BM column are due to the fact that CD45.1 mAb does not react with erythroid precursors in the marrow.

initial antibody course, but were undetectable at 38 weeks (Figure 8 ). Two mice were also tested at 68 weeks and anti-CD40 ligand antibody was not detected.

Finally, we have tested the presence of antigen-specific tolerization evaluating acceptance of donor B6.SJL $\left(\mathrm{H}-2^{\mathrm{b}}\right)$ and third-party $\mathrm{CBA} / \mathrm{J}\left(\mathrm{H}-2^{\mathrm{k}}\right)$ skin grafts into $\mathrm{H}-2$ mismatched $\mathrm{BALB} / \mathrm{c}$ mice, which had been subjected to B6.SJL spleen cell infusions with or without anti-CD40 ligand antibody blockade. Here B6.SJL marrow was infused into 100-cGy-treated hosts (the "standard protocol") and 8 to 9 and 39 to 43 weeks later BALB/c mice evaluated for acceptance or rejection of donor or third-party skin grafts. As shown in Table 2 skin donor grafts in marrow allochimeric mice were accepted and third-party CBA/J grafts rapidly rejected. Skin graft acceptance was durable out to 31 weeks. Control transplanted mice without marrow allochimerism or nontransplanted control BALB/c mice rejected both B6.SJL and CBA/J skin grants. Mice that received the double transplant (Figure 5) were grafted with both B6.SJL and CBA/J skin grafts at 37.5 weeks after first marrow infusion. One mouse was evaluated in group VII and 2 mice in group VIII. All skin grafts were promptly rejected.

\section{Discussion}

The present results establish a unique model for creation of nontoxic long-term stable high-level hematopoietic allochimerism. We have shown that antigen preexposure with concomitant CD40/ CD40 ligand costimulator blockade allows for high levels of chimerism with transplantation of 40 million $\mathrm{H}-2$ mismatched B6.SJL marrow to 100-cGy-treated BALB/c hosts. All components of the protocol appear essential because omission of antibody, spleen cell infusions, or irradiation results in low or absent levels of chimerism. The chimerism is long-term, over half the mouse's life span, and without evidence of GVHD. It is multilineage and shows a dose-response curve with regard to antibody dose. This dose-response result is of interest, especially given the relatively high amounts of CD40 ligand antibody demonstrating a clear dose response. This probably relates to the completeness of the costimulator blockade. This may be particularly so with a regimen including antigen (spleen cell) pre-exposure. Based on transplantation of 40 million B6.SJL marrow cells to $100-\mathrm{cGy}-$ treated C57BL/6 hosts (a histocompatible combination) the chimerism averaging $20 \%$ to $30 \%$ in B6.SJL to BALB/c hosts may be close to maximal for this level of infused cells, although higher levels of chimerism are seen when 40 million male BALB/c cells are transplanted to $100-\mathrm{cGy}$-treated female BALB/c hosts. However, increasing the level of transplanted B6.SJL cells to 80 million virtually doubled allochimerism and increasing the antibody level to $3.2 \mathrm{mg}$ /injection also increased the level of allochimerism. Thus chimerism can be obtained with a low-dose radiation regimen and with minimal toxicity. Although hamster immunoglobulin has been reported to accelerate collagen-induced arthritis, ${ }^{51}$ it showed no activity in inducing tolerance in our model.

In work by Markees and colleagues ${ }^{47,48}$ similar antigen-specific costimulator blockade approaches with skin allografts were evaluated with challenge skin grafts from the donor strain. Five mice
Figure 5. The effect of spleen cell preexposure on B6.SJL engraftment into 0-cGy or 100-cGy anti-CD40 ligand $m A b$-treated BALB/c hosts. Male BALB/c hosts either unirradiated (groups I-IV) or exposed to $100 \mathrm{cG}$ (groups V-VIII) were infused with 40 million male B6.SJL cells on day 0 and injected intraperitoneally with $1.6 \mathrm{mg}$ anti-CD40 ligand $\mathrm{mAb}$ on days $-10,-7,-3,0$, and +3 (groups II-IV and VI-VIII) or given no anti-CD40 ligand antibody (groups I and V). Spleen cell (SC) sensitization was omitted in groups II and $\mathrm{VI}$ or given on day -7 (groups III and VII) or day -10 (groups IV and VIII). Data are expressed as percentage (\%) CD45.1 cells in peripheral blood out to 31 weeks after transplantation. Ther were 5 transplanted mice per group initially. Between weeks 12 and 13 all mice received an infusion of 40 million B6.SJL (sex-matched) marrow cells. Asterisk indicate groups that had received a second marrow transplant; W, weeks; L, ligand; D, day.

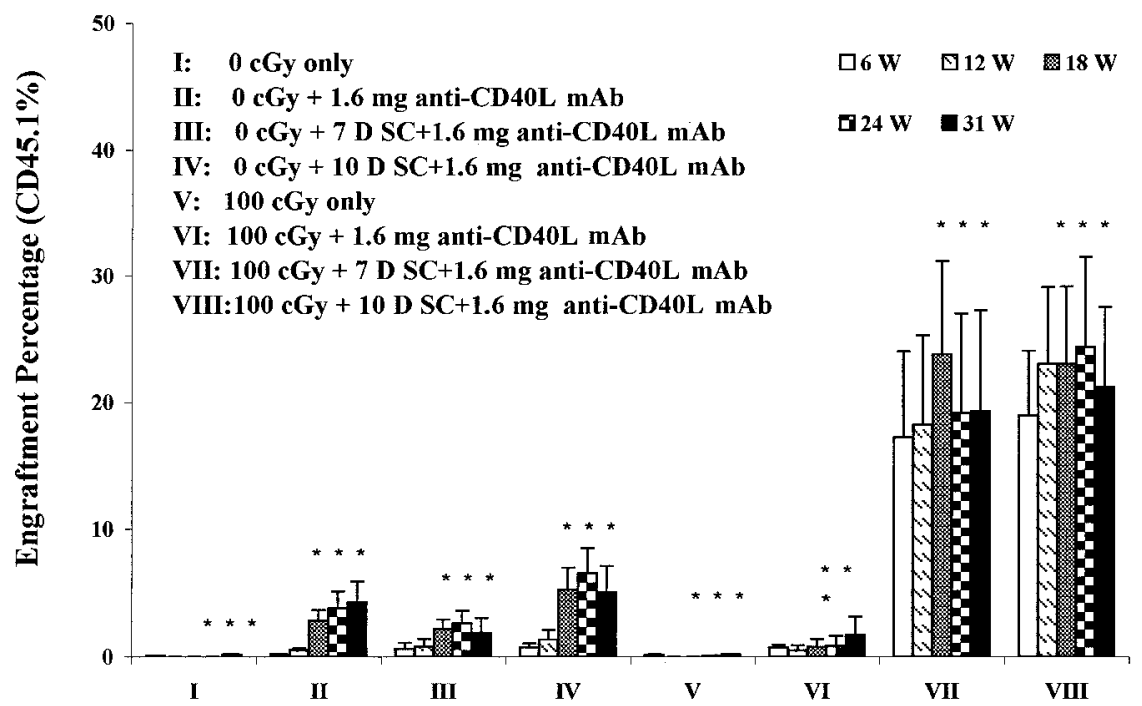




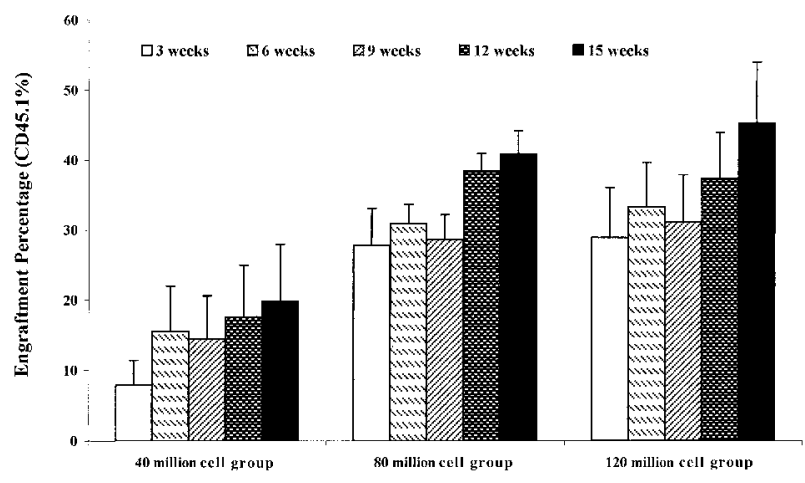

Figure 6. The effect of cell dose on engraftment of B6.SJL marrow cells into 100-cGy-irradiated BALB/c mice subjected to spleen cell pre-exposure and CD40 ligand blockade. BALB/c hosts irradiated with 100 cGy were infused with varying levels of B6.SJL marrow cells after splenic presensitization (day $-10,10$ million cells) and CD40 ligand antibody blockade (days $-10,-7,-3,0$, and +3 ) Results are expressed as percentage (\%) engraftment (CD45. $1^{+}$cells) \pm 1 SEM from 3 to 15 weeks after transplantation. There were 5 mice per group. There was a significant trend toward increasing engraftment as the cell doses increased; for weeks $3,6,9,12$, and 15 weeks $P$ values were $.01, .02, .12, .03$, and .03, respectively, although when analyzed independently with Wilcoxon rank order there was no significant difference between the 80 and 120 million cell groups.

whose primary skin allograft had survived for over 125 days showed variable results with the challenge grafts: one mouse rejected the challenge graft but retained the primary graft, one mouse accepted the challenge graft and maintained the primary graft, whereas 3 mice rejected both the primary and challenge grafts. ${ }^{47,48}$ Our initial studies with donor and third-party skin grafts in mice maintaining their marrow allografts show tolerance to donor skin grafts with rejection of the third-party skin grafts. Thus these mice show antigen-specific tolerance to both the marrow and late-skin H-2 mismatched allografts. Conversely, mice given a second marrow transplant (Figure 5) and then a skin graft showed prompt rejection of both donor and third-party skin grafts, while maintaining their marrow grafts, presumably a form of split tolerance.

Standard marrow transplantation approaches have used highdose ablative chemo/radio therapy for tumor killing to facilitate engraftment and to remove immune barriers. These approaches have an early treatment-related mortality and morbidity and still run the risk of graft rejection or GVHD. Solid organ transplantation

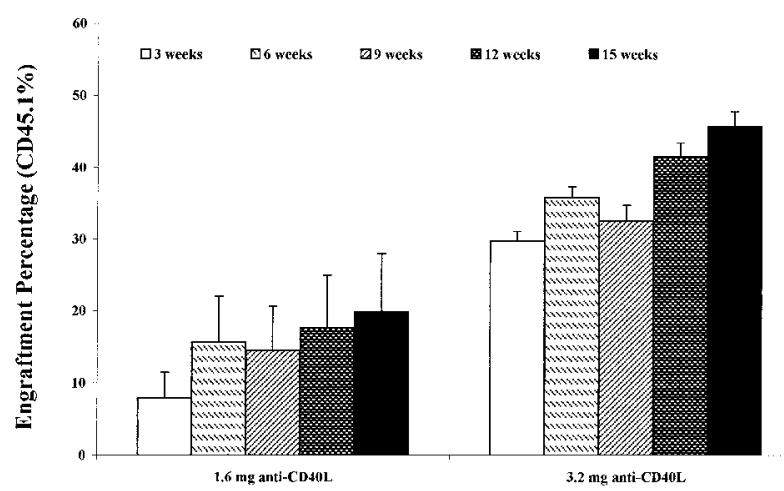

Figure 7. Engraftment of B6.SJL marrow cells into 100-cGy-irradiated, spleen pretreated BALB/c hosts injected with higher levels of anti-CD40 ligand mAb. $B A L B / c$ hosts were infused with 10 million B6.SJL spleen cells on day -10 and administered 1.6 or $3.2 \mathrm{mg}$ of anti-CD40 ligand $(\mathrm{L}) \mathrm{mAb}$ on days $-10,-7,-3,0$, and +3. As preparation for transplantation on day 0 BALB/c mice were exposed to 100 cGy WBI and infused with 40 million B6.SJL marrow cells. Engraftment of donor cells was determined as percentage (\%) CD45.1 cells in peripheral blood at 3 to 15 weeks after transplantation. There were 5 mice per group.

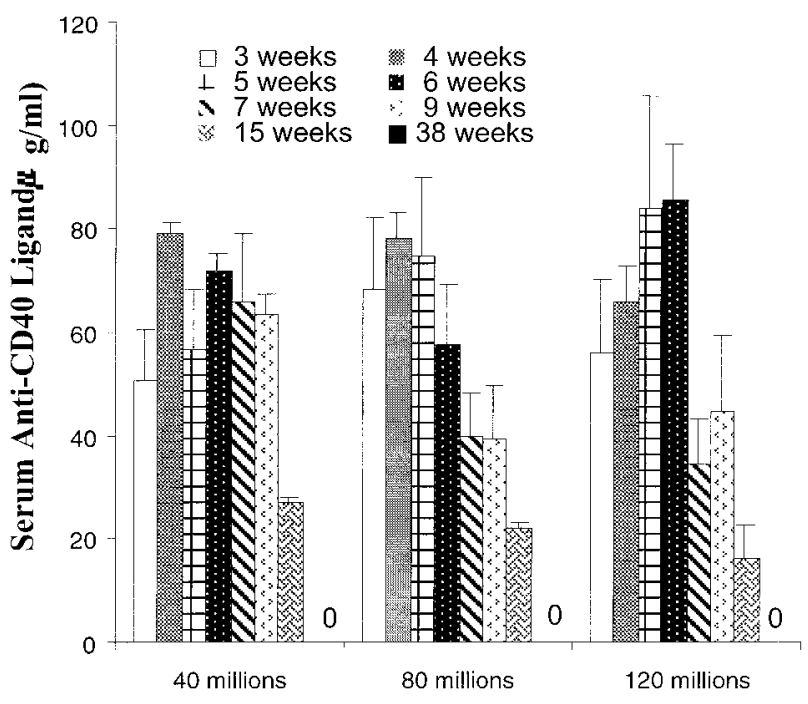

Figure 8. Serum clearance of anti-CD40 ligand mAb. Hamster anti-CD40 ligand $\mathrm{mAb}$ levels were determined by ELISA of serum at 3 to 38 weeks after last antibody injection (1.6 mg/injection). Serum levels from the groups presented in Figure 6 are shown. There were 5 mice per group through week 15; at week 38 there were 5 mice in the 40 million group, 2 mice in the 80 million group, and 3 mice in the 120 million group. Background values of 0 to $1.42 \mathrm{ng} / \mathrm{mL}$ were found in normal BALB/c mouse serum. Zero indicates no detectable antibody at 38 weeks.

has also required immediate and long-term immunosuppressive therapy with attendant risks. A number of attempts have been made to obtain allochimerism with less toxic/immunosuppressive therapy. Ildstad and colleagues ${ }^{52-55}$ have used a variety of approaches to lower WBI, including elimination of $\mathrm{CD}^{+}{ }^{+}$and $\mathrm{CD} 8^{+}$host $\mathrm{T}$ cells, cytoxan and antilymphocyte globulin treatment along with manipulation of T-cell receptor-CD8 ${ }^{+}$facilitator cells. ${ }^{56}$ Sykes and

Table 2. Skin graft results after transplant on BALB/c hosts

\begin{tabular}{|c|c|c|c|c|}
\hline Group & $\begin{array}{l}\text { Peripheral } \\
\text { blood } \\
\text { chimerism } \\
(\%)\end{array}$ & $\begin{array}{l}\text { Graft time } \\
\text { after BMT } \\
\quad(w k)\end{array}$ & $\begin{array}{l}\text { Skin graft } \\
\text { B6.SJL }\end{array}$ & $\begin{array}{c}\text { Skin graft } \\
\text { CBA/J }\end{array}$ \\
\hline \multirow[t]{5}{*}{ NormalBALB/c mice } & 0 & NA & - & - \\
\hline & 0 & NA & - & - \\
\hline & 0 & NA & - & - \\
\hline & 0 & NA & - & - \\
\hline & 0 & NA & - & - \\
\hline \multirow{10}{*}{$\begin{array}{l}\text { Standard protocol } \\
\text { (1.6 mg anti-CD40 } \\
\text { ligand antibody) }\end{array}$} & 46.1 & 8 & $+(>7 w k)$ & - \\
\hline & 37.9 & 8 & $+(>7 w k)$ & - \\
\hline & 40.9 & 8 & $+(>7 w k)$ & - \\
\hline & 33.3 & 9 & $+(>7 w k)$ & - \\
\hline & 35.6 & 9 & $+(>7 w k)$ & - \\
\hline & 26.7 & 39 & $+(>6 w k)$ & - \\
\hline & 30.3 & 39 & $+(>6 w k)$ & - \\
\hline & 31.3 & 39 & $+(>6 w k)$ & - \\
\hline & 27.6 & 43 & $+(>31 \mathrm{wk})$ & - \\
\hline & 31.5 & 43 & $+(23 w k)^{*}$ & - \\
\hline \multirow{6}{*}{$\begin{array}{l}\text { Standard protocol or } \\
\text { variants of standard } \\
\text { protocol }\end{array}$} & 0.1 & 8 & - & - \\
\hline & 0.03 & 8 & - & - \\
\hline & 0.33 & 39 & - & - \\
\hline & 0 & 39 & - & - \\
\hline & 0 & 43 & - & - \\
\hline & 0 & 43 & - & - \\
\hline
\end{tabular}

Grafts transplanted on the dorsal surface with B6.SJL on the left and CBA/J on the right side.

BMT indicates bone marrow transplant; NA, not applicable; - rejection (rejection was completed within 10-12 days of graft application); + , accepted graft (number of weeks in parentheses represents duration of graft after graft application).

* This mouse died at 56 weeks after marrow graft, 23 weeks after skin graft; cause unknown. 
Table 3. Components of regimen that may facilitate long-term tolerance or engraftment potential

\begin{tabular}{lc}
\hline Component of regimen & \multicolumn{1}{c}{ Mode of action } \\
\hline High levels of stem cells & $\begin{array}{c}\text { Inherently tolerizing or proper } \\
\text { number of modulatory cells } \\
\text { Minimize "cytokine storm" }\end{array}$ \\
$\begin{array}{l}\text { Nonablative host } \\
\text { treatment }\end{array}$ \\
$\begin{array}{l}\text { antigen presensitization } \\
\text { antibody blockade }\end{array}$ \\
\hline
\end{tabular}

colleagues ${ }^{57}$ have achieved allochimerism without myelosuppressive host conditioning, using a B10.A to B6 marrow transplant model with depleting anti-CD4 and anti-CD8 mAbs, local thymic irradiation, and a high dose $\left(174 \times 10^{6}\right)$ of major histocompatibilitymismatched (B10.A) marrow cells divided over days 0 through 4. These investigators, as noted above, recently used combined costimulator blockade with a WBI dose of $300 \mathrm{cGy}$, a lower dose of marrow, and no T-cell-depleting antibodies or thymic irradiation, and obtained long-term stable hematopoietic chimerism. More recently, using a congenic $\mathrm{H}-2$ mismatched model (a less rigorous transplant model than B6.SJL to BALB/c), 200 million marrow cells into nonirradiated hosts with CD40 ligand mAb and CTLA4 Ig treatment, Wekerle and colleagues ${ }^{58}$ obtained low-level multilineage chimerism in 9 of 14 transplanted mice out to 30 weeks. This was similar to the levels of engraftment at 31 weeks demonstrated in our delayed transplants with no irradiation and with or without spleen cell pre-exposure presented in Figure 4 (groups II and IV). These BALB/c mice received a total of 80 million B6.SJL cells. Storb and colleagues, using posttransplantation immune suppression/ modulation with cyclosporine and mycophenolate mofetil in a DLA identical canine transplant model, have also significantly lowered the irradiation dose needed to obtain allochimerism. ${ }^{59}$ Reisner and colleagues ${ }^{60-63}$ have suggested that stem cells expressing class I and class II without costimulator expression may be tolerizing and that high levels of purified stem cells may provide a means of obtaining long-term tolerance. In a related vein, others have suggested that various marrow cell populations could induce specific tolerance to donor-type antigens either by exhibiting specific suppression or inducing anergy of cytotoxic T-lymphocyte progenitors. These subpopulations include "natural" suppressors ${ }^{64}$; CD8 nonalloreactive T cells ${ }^{65}$; $\mathrm{CD}^{+}, \mathrm{CD}^{+}, \mathrm{CD} 45 \mathrm{R}^{+}$, Thy- $1^{+}$, and $\mathrm{TCR}^{-}$"facilitator" cells ${ }^{56}$; and $\mathrm{CD} 2^{+}, \mathrm{CD} 8^{+}, \mathrm{CD}_{16}{ }^{+}, \mathrm{DR}^{-}$, $\mathrm{CD}^{-}$, and $\mathrm{CD}^{-} 8^{-}{ }^{-}$cells. ${ }^{66}$

Thus, part of the effectiveness of our approach, using antigenspecific preexposure combined with anti-CD40 ligand blockade, high levels of marrow cells, and nonablative (100 cGy) host treatment, may be the infusion of appropriate numbers of tolerizing stem cells or tolerizing cells without stem cell potential. In addition, Ferrara ${ }^{67}$ has described the phenomenon of "cytokine storm" occurring with cytoablative therapy and potentially inducing GVHD. Low-dose host treatment would minimize or eliminate this potentially deleterious effect. Finally, costimulator blockade in the context of antigen presentation is a specific approach for inducing antigen-specific tolerance. Thus, the present approach combines multiple elements that may induce tolerance or diminish immune reactivity as presented in Table 3 .

The model described here is both nontoxic and flexible. It would appear that the percent donor chimerism can be altered by altering the cell level infused or antibody level injected. In unpublished studies (H.W., S.Z., F.M.S., P.J.Q.) we have shown that $30 \%$ to $40 \%$ chimerism in $\mathrm{Hbb}^{\text {th }} / \mathrm{Hbb}^{\text {th }}$ thalassemia mice ${ }^{68}$ corrects the anemia of these mice. Other studies have shown that partial allochimerism in human thalassemia transplant potentially leads to correction of the anemia. ${ }^{69,70}$ These data suggest that the present approach might be used in humans to purposefully create nontoxic partial allochimerism to correct the anemia in patients with thalassemia or sickle cell anemia. ${ }^{69-71}$ This type of approach using CD40 ligand mAb for a costimulator blockage might be complicated by thromboembolic toxicity as recently observed in both primates and humans. ${ }^{72,73}$ However, this has not been a universal experience, and the specifics of the antibody preparation rather than the CD40-CD40 ligand blockade may be the problem. ${ }^{72}$ Similar approaches will be of interest in the immune therapy of cancer and in transplant for autoimmune diseases.

\section{References}

1. Schofield R. The relationship between the spleen colony-forming cell and the haemopoietic stem cell. Blood. 1978;4:7-25.

2. Micklen HS, Clarke CM, Evans EP, Ford CE. Fate of chromosome-marked mouse bone marrow cells transfused into normal syngeneic recipients. Transplantation. 1968;6:299-302.

3. Takada A, Takada Y, Ambrus JL. Proliferation of donor spleen and marrow cells in the spleens and bone marrows of unirradiated and irradiated adult mice. Proc Soc Exp Biol Med. 1970;136:222-226.

4. Takada Y, Takada A. Proliferation of donor hematopoietic cells in irradiated and unirradiated host mice. Transplantation. 1971;12:334-338.

5. Brecher G, Ansell JD, Micklem HS, Tjio JH, Cronkite EP. Special proliferative sites are not needed for seeding and proliferation of transfused bone marrow cells in normal syngeneic mice. Proc Nat Acad Sci U S A. 1982;79:5085-5087.

6. Saxe DF, Boggs SS, Boggs DR. Transplantation of chromosomally marked syngeneic marrow cells into mice not subjected to hematopoietic stem cell depletion. Exp Hematol. 1984;12:277283.

7. Stewart FM, Crittenden R, Lowry PA, PearsonWhite S, Quesenberry PJ. Long-term engraftment of normal and post-5-fluorouracil murine marrow into normal nonmyeloablated mice. Blood. 1993;81:2566-2571.

8. Ramshaw HS, Rao SS, Crittenden RB, Peters SO, Weier HU, Quesenberry PJ. Engraftment of bone marrow cells into normal unprepared hosts: effects of 5-fluorouracil and cell cycle status. Blood. 1995;86:924-929.

9. Ramshaw H, Crittenden RB, Dooner M, Peters S0, Rao SS, Quesenberry PJ. High levels of engraftment with a single infusion of bone marrow cells into normal unprepared mice. Biol Blood Marrow Transplant. 1995;1:74-80

10. Blomberg ME, Rao, SS, Reilly JL, et al. Repetitive bone marrow transplantation in nonmyeloablated recipients. Exp Hematol. 1998;26:320-324.

11. Rao SS, Peters S, Critten RB, Stewart FM, Ram shaw HS, Quesenberry PJ. Stem cell transplantation in the normal nonmyeloablated host: relationship between cell dose, schedule and engraftment. Exp Hematol. 1997;25:114-121.

12. Stewart FM, Zhong S, Wuu J, Hsieh CC, Nilsson SK, Quesenberry PJ. Lymphohematopoietic engraftment in minimally myeloablated hosts. Blood. 1998;91:3681-3687

13. Allison JP. CD28-B7 interactions in T-cell activation. Curr Opin Immunol. 1994;6:414-419.

14. Jenkins MK, Taylor PS, Norton SD, Urdahl KB.
CD28 delivers a costimulatory signal involved in antigen-specific IL-2 production by human T cells. J Immunol. 1991:147:2461-2466.

15. Boussiotis VA, Freeman GJ, Gray G, Gribben J, Nadler LM. B7 but not intercellular adhesion molecule-1 costimulation prevents the induction of human alloantigen-specific tolerance. J Exp Med. 1993;178:1753-1763.

16. Schwartz RH. Costimulation of T lymphocytes: the role of CD28, CTLA-4, and B 7/BB I in interleukin-2 production and immunotherapy. Cell. 1992;71:1065-1068.

17. Armitage RJ, Fanslow WC, Srockbine L, et al. Molecular and biological characterization of a murine ligand for CD40. Nature. 1992;357:80-82.

18. Cayabyab M, Phillips JH, Lanier LL. CD40 preferentially co-stimulates activation of $\mathrm{CD} 4^{+} \mathrm{T}$ lymphocytes. J Immunol. 1994;152:1523-1531.

19. Hollenbaugh D, Mischel-Petty N, Edwards CP, et al. Expression of functional CD40 by vascular endothelial cells. J Exp Med. 1995;182:33-40.

20. Grewal IS, Xu J, Flavell RA. Impairment of antigen-specific T-cell priming in mice lacking CD40 ligand. Nature. 1995;378:617-620.

21. Grewal IS, Foellmer HG, Grewal KD, et al. Requirement of CD40 ligand in costimulation induction, T-cell activation, and experimental allergic 
encephalomyelitis. Science. 1996;273:18641867.

22. Schwartz RH. A cell culture model for T lymphocyte clonal anergy. Science. 1990;248:13491356.

23. Lin H, Bolling SF, Linsley PS. Long-term acceptance of major histocompatibility complex mismatched cardiac allografts induced by CTLA4 Ig plus donor-specific transfusion. J Exp Med. 1993; 178:1801-1806

24. Steurer W, Nickerson PW, Steele AW, Steiger J, Zheng XX, Strom TB. Ex vivo coating of islet cell allografts with murine CTLA4/Fc promotes graft tolerance. J Immunol. 1995;155:1165-1174.

25. Russell ME, Hancock WW, Akalin E, et al. Chronic cardiac rejection in the LEW to F344 rat model blockade of CD28-B7 costimulation by CTLA4 Ig modulates T cell and macrophage activation and attenuates arteriosclerosis. J Clin Invest. 1996;97:833-838.

26. Pearson TC, Alexander DZ, Winn KJ, Linsley PS Lowry PA, Larsen CP. Transplantation tolerance induced by CTLA4-Ig. Transplantation (Baltimore). 1996;57:1701-1706.

27. Azuma H, Chandraker A, Nadeau K, et al. Blockade of T-cell costimulation prevents development of experimental chronic renal allograft rejection. Proc Natl Acad Sci U S A. 1996;93:12439-12444.

28. Yin DP, Sankary HN, Williams J, Krieger N, Fathman CG. Induction of tolerance to small bowel allografts in high-responder rats by combining anti-CD4 with CTLA4 Ig. Transplantation (Baltimore). 1996;62:1537-1539.

29. Lin H, Bolling SF, Linsley PS, et al. Long-term acceptance of major histocompatibility complex mismatched cardiac allografts induced by CTLA4Ig plus donor-specific transfusion. J Exp Med. 1993;178:1801-1806.

30. Lenschow D, Zeng Y, Thistlethwaite JR, et al Long-term survival of xenogeneic pancreatic islet grafts induced by CTLA4 Ig. Science. 1992;257: 789-792.

31. Turka LA, Linsley PS, Lin $\mathrm{H}$, et al. T-cell activation by the CD28 ligand B7 is required for cardiac allograft rejection in vivo. Proc Natl Acad Sci U S A 1992;89:11102-11105.

32. Larsen CP, Alexander DZ, Hollenbaugh ET, et al. CD40-gp39 interactions play a critical role during allograft rejection. Suppression of allograft rejection by blockade of the CD40-gp39 pathway. Transplantation. 1996;61:4-9.

33. Parker DC, Greiner DL, Phillips NE, et al. Surviva of mouse pancreatic islet allografts in recipients treated with allogeneic small lymphocytes and antibody to CD40 ligand. Proc Natl Acad Sci U S A. 1995;92:9560-9564.

34. Larsen CP, Elwood ET, Alexander DZ, et al. Long term acceptance of skin and cardiac allografts after blocking CD40 and CD28 pathways. Nature. 1996;381:434-438.

35. Elwood ET, Larsen CP, Cho HR, et al. Prolonged acceptance of concordant and discordant xenografts with combined CD40 and CD28 pathway blockade. Transplantation. 1998;65:1422-1428.

36. Durie FH, Aruffo J, Ledbetter KM, et al. Antibody to the ligand of CD40, gp39, blocks the occurrence of the acute and chromic forms of graftversus-host disease. J Clin Invest. 1994:94:1333 1338.

37. Blazar BR, Taylor PA, Panoskaltsis-Mortari A, et al. Blockade of CD40 ligand CD40 interaction impairs CD4 ${ }^{+} \mathrm{T}$ - cell-mediated alloreactivity by inhibiting mature donor T-cell expansion and function after bone marrow transplantation. J Immunol. 1997;158:29-39.

38. Wekerle T, Sayegh MH, Hill J, et al. Extrathymic T-cell deletion and allogeneic stem cell engraftment induced with costimulatory blockade is fol- lowed by central T-cell tolerance. J Exp Med. 1998;187:2037-2044.

39. Kirk AD, Harlan DM, Armstrong NN, et al. CTLA4-Ig and anti-CD40 ligand prevent renal alograft rejection in primates. Proc Natl Acad Sci U S A. 1997;94:8789-8794.

40. Storb RC, Yu C, Zaucha JM, et al. Stable mixed hematopoietic chimerism in dogs given donor antigen, CTLA4Ig, and 100 cGy total body irradiation before and pharmacologic immunosuppression after marrow transplant. Blood. 1999;94: 2523-2529.

41. Laman JD, Claassen E, Noelle R-J. Functions of CD40 and its ligand, gp39 (CD40L). Crit Rev Immunol. 1996;16:59-108.

42. Foy TM, Aruffo A, Bajorath J, Buhlmann JE, Noelle RJ. Immune regulation by CD40 and its ligand gp39. Annu Rev Immunol. 1996;14:591617.

43. Lenschow DJ, Walunas TL, Bluestone JA. CD28/B7 system of T-cell costimulation. Annu Rev Immunol. 1996;14:233-258.

44. Parker DC, Greiner DL, Phillips NE, et al. Survival of mouse pancreatic islet allografts in recipients treated with allogeneic small lymphocytes and antibody to CD40 ligand. Proc Natl Acad Sci U S A. 1995:92:9560-9564

45. Rossini AA, Parker DC, Phillips NE, et al. Induction of immunological tolerance to islet grafts. Cell Transplant. 1996;5:49-52.

46. Markees TG, Appel MC, Noelle RJ, Mordes JP, Griener DL, Rossini AA. Tolerance to islet xenografts induced by dual manipulation of antigen presentation and co-stimulation. Transplant Proc. 1996;28:814-815.

47. Markees TG, Phillips NE, Noelle RJ, et al. Prolonged survival of mouse skin allografts in recipients treated with donor splenocytes and antibody to CD40 ligand. Transplantation. 1997;64:329335.

48. Markees TG, Phillips NE, Gordon EJ, et al. Long term survival of skin allografts induced by donor splenocytes and anti-CD 154 antibody in thymectomized mice requires CD4(=) T-cells, interferongamma, and CTLA4. J Clin Invest. 1998;101: 2446-2455.

49. Cuzick JA: Wilcoxon-type test for trend. Stat Med. 1985;4:87-90

50. Yuhas JM, Storer JB. On mouse strain differences in radiation resistance: hematopoietic death and endogenous colony forming unit. Rad Res. 1969;39:608.

51. Durie FH, Fava RA, Foy TM, Aruffo A, Ledbetter JA, Noelle RJ. Prevention of collagen-induced arthritis with an antibody to gp39, the ligand for CD40. Science. 1993;261:1328-1330.

52. Colson YL, Wren SM, Schuchert MJ, et al. A non lethal conditional approach to achieve durable multilineage mixed chimerism and tolerance across major, minor, and hematopoietic histocompatibility barriers. J Immunol. 1995;155:41794188.

53. Li H, Kaufman CL, Boggs SS, Johnson PC, Patrene KD, Ildstad ST. Mixed allogeneic chimerism induced by a sublethal approach prevents autoimmune diabetes and reverses insulitis in nonobese diabetic (NOD) mice. J Immunol. 1996; 156:380-388.

54. Colson YL, Li H, Boggs SS, Patrene KD, Johnson PC, Ildstad ST. Durable mixed allogeneic chimerism and tolerance by a non-lethal radiationbased cytoreductive approach. J Immunol. 1996 157:2820-2829.

55. Exner BG, Colson YL, Li H, Ildstad ST. In vivo depletion of host $\mathrm{CD} 4^{+}$and $\mathrm{CD} 8^{+}$cells permits engraftment of bone marrow stem cells and tolerance induction with minimal conditioning. Surgery. 1997;122:221-227.
56. Kaufman CL, Colson YL, Wren SM, Watkins S Simmons RL, Ildstad ST. Phenotypic characterization of a novel bone marrow-derived cell that facilitates engraftment of allogeneic bone marrow stem cells. Blood. 1994;84:2436-2446.

57. Sykes M, Szot GL, Swenson KA, Pearson DA. Induction of high levels of allogeneic hematopoietic reconstitution and donor-specific tolerance without myelosuppressive conditioning. Nat Med. 1997;3:783-787.

58. Wekerle T, Kurtz J, Ito $\mathrm{H}$, et al. Allogeneic bone marrow transplantation with costimulator blockade induces macrochimerism and tolerance without cytoreductive host treatment. Nat Med. 2000 6:464-469.

59. Storb RC, Yu JL, Wagner GJ, et al. Stable mixed hematopoietic chimerism in DLA-identical littermate dogs given sub-lethal total body irradiation before and pharmacological immunosuppression after marrow transplantation. Blood. 1997;89: 3048-3054.

60. Rachamin NJ, Gan H, Segall R, et al. Tolerance induction by "megadose" hematopoietic transplants. Transplantation. 1998;65:1386-1393.

61. Aversa F, Tabilio A, Tereuzi A, et al. Successful engraftment of T-cell-depleted haploidentica "three-loci" incompatible transplants in leukemia patients by addition of recombinant human granulocyte colony-stimulating factor-mobilized peripheral blood progenitor cells to bone marrow inoculant. Blood. 1994;84:3948-3955.

62. Bachar-Lustig E, Rachamin N, Li HW, Lan F, Reisner Y. Megadose of T-cell depleted bone marrow overcomes NMC barriers in sublethally irradiated mice. Nat Med. 1995;1:1268-1273.

63. Reisner Y, Bachar-Lustig E, Li H-W. Sca-1+ Linhematopoietic stem cells and non-alloreactive T-cells exhibit a potent tolerizing activity in sublethally irradiated recipients; a model for tolerance induction by "megadose" stem cell transplants. Acta Hematol. 1997;98:10.

64. Strober S. Natural suppressor (NS) cells, neonatal tolerance, and total lymphoid irradiation: exploring obscure relationships. Annu Rev Immunol. 1984;2:219-237.

65. Lapidot T, Faktorowich Y, Lubin I, Reisner Y. Enhancement of T-cell-depleted bone marrow allografts in the absence of graft-versus-host disease is mediated by $\mathrm{CD} 8^{+} \mathrm{CD} 4^{-}$and not by CD8- CD4 ${ }^{+}$thymocytes. Blood. 1992;80:2406 2411

66. Thomas JM, Carver FM, Cunningham PR, Olson LC, Thomas FT. Kidney allograft tolerance in primates without chronic immunosuppression-the role of veto cells. Transplantation. 1991;51:198207.

67. Ferrara JL. Cytokine dysregulation as a mechanism of graft-versus-host disease. Curr Opin Immunol.1993;5:794-799.

68. Skow LC, Burkhart BA, Johnson FM, et al. A mouse model for $\beta$-thalassemia. Cell. 1983;34: 1043-1052.

69. Andrealli MM, Manna G, Lucarelli P, et al. Persistence of mixed chimerism in patients transplanted for the treatment of thalassemia. Blood. 1996;97: 3494-3499.

70. Kapelushnik J, Or R, Rilon D, et al. Analysis of $\beta$-globin mutations shows stable mixed chimerism in patients with thalassemia after bone marrow transplantation. Blood. 1995;86:3241-3246.

71. Walters MC, Patience M, Leisenring W, et al. Bone marrow transplantation for sickle cell disease. New Engl J Med. 1996;335:369-376.

72. Kawai T, Andrews D, Colvin RB, Sachs DHX, Cosimi AB. Thromboembolic complications after treatment with monoclonal antibody against CD40 ligand. Nat Med. 2000;6:114.

73. Vincent J. Biogen News. http:\\www.prnewswire. com 11/02/99 